Journal of Telenursing (JOTING)

Volume 2, Nomor 2, Desember 2020

e-ISSN: 2684-8988

p-ISSN: 2684-8996

DOI: https://doi.org/10.31539/joting.v2i2.1440

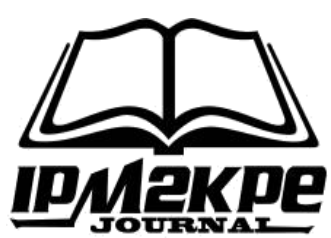

\title{
PENURUNAN SKALA NYERI DISMENORE PRIMER PADA REMAJA PUTRI MENGGUNAKAN MASASE EFFLEURAGE
}

\author{
Muhammad Amin ${ }^{1}$, Yesi Purnamasari ${ }^{2}$ \\ Universitas Muhammadiyah Bengkulu ${ }^{1,2}$ \\ mamin@umb.ac.id ${ }^{1}$
}

\begin{abstract}
ABSTRAK
Tujuan penelitian ini adalah untuk mengetahui skala nyeri sebelum dan sesudah diberikan terapi masase effleurage remaja putri yang mengalami dismenore primer. Metode penelitian yang digunakan dalam penelitian ini adalah metode pra-eksperiment dengan rancangan pretest-postest. Hasil penelitian menunjukkan bahwa nilai p sebelum dan sesudah diberikan terapi masase effleurage adalah $0,000(<0,05)$. Simpulan, ada pengaruh terapi masase effleurage terhadap penurunan skala nyeri dismenore primer pada remaja putri di SMP Muhammadiyah Terpadu Kota Bengkulu.
\end{abstract}

Kata Kunci : Dismenore Primer, Masase Effleurage, Skala Nyeri

\section{ABSTRACT}

This study aimed to determine the scale of pain before and after being given effleurage massage therapy for adolescent girls experiencing primary dysmenorrhea. The research method used in this study is a pre-experimental method with a pretest-postest design. The results showed that the p-value before and after being given effleurage massage therapy was 0.000 (<0.05). In conclusion, there is an effect of effleurage massage therapy on reducing the pain scale of primary dysmenorrhea in young women at SMP Muhammadiyah Terpadu, Bengkulu City.

Keywords: Primary Dysmenorrhea, Effleurage Massage, Pain Scale

\section{PENDAHULUAN}

Perubahan fisik, perilaku, kognitif, biologis, dan emosi merupakan beberapa perubahan yang dialami oleh remaja yang berada antara fase anak dan dewasa. Remaja memasuki usia pubertas mulai mengalami banyak perubahan fisik maupun psikologis, salah satu perubahan tersebut yaitu ketika memasuki masa menstruasi atau haid, menstruasi adalah proses alamiah yang terjadi pada perempuan (Febriawati et al., 2018). menstruasi merupakan perdarahan teratur dari uterus sebagai tanda bahwa alat kandungan telah menunaikan fungsinya, masa ini akan mengubah perilaku dari berbagai aspek. Menstruasi biasa dimulai antara umur 12-16 tahun selama 2-7 hari (Kusmiran, 2012).

Pada masa ini juga terjadi kemajuan pesat pada kematangan fungsi organ seksual atau dengan kata lain mengalami pubertas dan ditandai dengan menstruasi pertama pada remaja perempuan (Hurlock, 2010). Menstruasi memiliki arti yaitu perdarahan secara periodik dan siklik yang berasal dari rahim disertai dengan melepasnya lapisan endometrium (Prawirohardjo, 2011). 
Gangguan nyeri menstruasi atau dismenore adalah masalah yang sering dialami oleh remaja (Kusmiran, 2012). Dismenore bisa terjadi karena ketidakseimbangan hormon progesterone dalam darah sehingga menimbulkan nyeri yang terjadi pada wanita (Prayitno, 2014). Remaja putri yang mengalami gangguan nyeri menstruasi sangat menggangu dalam proses belajar mengajar, yang menyebabkan sulitnya remaja putri untuk konsentrasi karena perasaan tidak nyaman yang dirasakan pada saat nyeri haid, sehingga dismenore harus ditangani agar tidak terjadi dampak yang lebih buruk bagi remaja (Nirwana, 2011).

Dismenore terdiri dari dismenore primer dan sekunder, nyeri haid yang ditemukan tanpa adanya kelainan pada alat-alat genital yang nyata sering disebut dismenore primer, sedangkan nyeri yang dirasakan pada saat menstruasi yang disebabkan oleh kelainan ginekologi atau kandungan dismenore sekunder (Kusmiran, 2012; Inayah, 2010).

Angka kejadian dismenore di dunia cukup tinggi, 50\% dari seluruh wanita di dunia menderita dismenore dalam siklus menstruasi yang menjadi penyebab wanita tidak bisa melakukan apapun kegiatan yang ingin dilakukan (Calis, 2011). Sedangkan data dari National Health and Nutrition Examination Survey (NHANES) dismenore mayoritas terjadi pada remaja dengan angka kejadian 43-93\% (Hestiantoro, 2012)

Di Indonesia angka kejadian dismenore sebesar $64,25 \%$ yang terdiri dari dismenore primer sebesar 54,89\% dan dismenore sekunder 9,36\% (Proverawati, 2012). $14 \%$ dari pasien remaja sering tidak hadir ke sekolah dan tidak menjalani kegiatan sehari-hari disebabkan oleh dismenore (Calis, 2011).

Nyeri yang diakibatkan oleh kontraksi uterus memerlukan berbagai penanganan untuk meminimalkan rasa nyeri yang dirasakan oleh ibu sehingga kenyamanan ibu dapat kembali. Peran seorang perawat pada kondisi tersebut adalah membantu meredakan nyeri ibu post partum dengan memberikan intervensi dalam meredakan nyeri (Andarmoyo, 2013). Nyeri dapat diatasi dengan berbagai cara, ada yang menggunakan cara farmakologis ada juga yang menggunakan cara non farmakologis, secara farmakologis bisa diatasi menggunakan obat-obatan analgesik, sedangkan secara non farmakologis nueri tersebut bisa diatasi dengan cara kompres panas dan dingin, stimulasi saraf elektris transkutan, distraksi, relaksasi, imajinasi terbimbing, hipnosis, akupuntur, umpan balik biologis, dan masase effleurage (Trisnowiyoto, 2012).

Masase effleurage akan mengurangi hipoksia pada jaringan sehingga terjadi peningkatan kadar oksigen di jaringan dan menyebabkan nyeri berkurang. Pemberian terpai masase effleurage juga dapat menyebabkan terjadinya pelepasan hormon endorfin sehingga ambang nyeri meningkat (Apay et al., 2012).

Sejalan dengan penelitian Nurkhasanah \& Fitrisia (2014) dari hasil penelitian menunnjukkan bahwa nilai $\mathrm{p}=0,000$ sehingga terdapat perbedaan yang signifikan antara intensitas skala nyeri dismenore sebelum dan sesudah dilakukan masase effleurage.

Sejalan dengan penelitian Parulian et al., (2014) menunjukkan ada pengaruh teknik effleurage massage terhadap perubahan nyeri pada ibu post partum, dengan hasil p-value (0,000). Penelitian yang dilakukan Wulandari \& Hiba (2015) menunjukkan ada pengaruh massage effleurage terhadap pengurangan tingkat nyeri persalinan kala 1 fase aktif pada primigravida diruang bougenville RSUD Tugurejo Semarang, didapatkan nilai $\mathrm{p}$-Value $=0,000$. 


\section{METODE PENELITIAN}

Jenis penelitian ini merupakan penelitian kuantitatif dengan desain eksperimental rancangan pra eksperimen dengan metode pendekatan one group pre and posttest design. Penelitian ini dilaksanakan di SMP Muhammadiyah Terpadu Kota Bengkulu pada tanggal 9 Maret- 9 April 2017.

Populasi dalam penelitian ini seluruh siswi SMP Muhammadiyah Terpadu Kota Bengkulu tahun ajaran 2016/2017 yang berjumlah 119 orang. Pengambilan sampel dalam penelitian ini dengan menggunakan non probability sampling dengan metode consecutive sampling, sampel minimum yang disarankan dalam penelitian eksperimen yaitu 15 subyek per group yang dilakukan selama kurun waktu 1 bulan dan pada saat penelitian yang dimasukkan kedalam penelitian adalah responden yang mengalami nyeri haid primer dari hari 1-3, remaja putri berusia 12-16 tahun, belum pernah menikah atau melahirkan, memiliki siklus haid yang teratur 3 bulan terakhir (24-35 hari), bersedia menjadi responden, serta tidak menggunakan obat analgesik dan pengobatan non farmakologi yang lain seperti minum jamu, kompres hangat dan yang lain saat intervensi dilakukan. Sedangkan remaja putri yang mengalami nyeri di bagian tubuh yang lain, dan remaja putri yang mengalami nyeri abdomen selain nyeri haid, seperti gastritis, sedang mengalami pengobatan dengan obat penghilang nyeri, serta yang pernah mengalami operasi di daerah abdomen dan pelvis tidak dimasukkan kedalam penelitian.

Analisis data yang digunakan jika data berdistribisi normal menggunakan uji t dependen, jika data tidak berdistribusi normal maka uji analisis yang digunakan adalah uji non parametrik.

\section{HASIL PENELITIAN}

Tabel. 1

Distribusi Frekuensi Skala Nyeri Dismenore Primer Sebelum Diberikan Intervensi Terapi Masase Effleurage Abdomen pada Remaja Putri

\begin{tabular}{ccc}
\hline Skala Nyeri (Pre test) & $\mathrm{N}$ & Presentase $(\%)$ \\
\hline 1-3 (Nyeri Ringan) & 3 & 20,0 \\
4-6 (Nyeri Sedang) & 12 & 80,0 \\
\hline Total & 15 & 100,0 \\
\hline
\end{tabular}

Berdasarkan tabel 1 menunjukkan bahwa mayoritas skala nyeri dismenore primer sebelum terapi masase effleurage termasuk kedalam kategori nyeri sedang (4-6) sebanyak 12 orang $(80,0 \%)$.

Tabel. 2

Distribusi Frekuensi Skala Nyeri Dismenore Primer Sesudah Diberikan Intervensi Terapi Masase Effleurage Abdomen pada Remaja Putri

\begin{tabular}{ccc}
\hline Skala Nyeri (Pos test) & $\mathrm{N}$ & Presentase $(\%)$ \\
\hline 0 (Tidak Nyeri) & 3 & 20,0 \\
1-3 (Nyeri Ringan) & 10 & 66,7 \\
4-6 (Nyeri Sedang) & 2 & 13,3 \\
\hline Total & 15 & 100,0 \\
\hline
\end{tabular}


Berdasarkan tabel 1 menunjukkan bahwa mayoritas skala nyeri dismenore primer sebelum terapi masase effleurage termasuk kedalam kategori nyeri ringan (1-3) sebanyak 10 orang $(66,7 \%)$.

Tabel. 3

Distribusi Rata-rata Skala Nyeri Dismenore Primer pada Remaja Putri Menurut Pengukuran Pre Test dan Post Test

\begin{tabular}{lccccc}
\hline Skala Nyeri & Mean & $S D$ & $S E$ & $\begin{array}{l}p . \\
\text { value }\end{array}$ & $\mathrm{N}$ \\
\hline Pre test & 4,2 & 1,20 & 0,3 & 0,000 & 15 \\
Pos test & 1,9 & 1,33 & 0,3 & & \\
\hline
\end{tabular}

Berdasarkan tabel 3 menunjukkan bahwa rata-rata skala nyeri dismenore primer sebelum diberikan terapi masase effleurage abdomen adalah 4,20, setelah diberikan intervensi rata-rata skala nyeri adalah 1,93 . Hasil hasil analisis bivariat menunjukkan $\mathrm{P}$ value $0,000<0,05$, terdapat pengaruh terapi masase effleurage abdomen terhadap penurunan skala nyeri dismenore primer pada remaja putri di SMP Muhammadiyah Terpadu Kota Bengkulu.

\section{PEMBAHASAN}

\section{Skala Nyeri Dismenore Primer Sebelum Diberikan Terapi Masase Effleurage}

Hasil dalam penelitian ini menunjukkan bahwa dari 15 responden mayoritas menderita nyeri haid pada skala 4-6 (nyeri sedang). Disini peneliti menyimpulkan bahwa tingginya kadar prostaglandin dalam darah merupakan penyebab terjadinya nyeri haid pada responden. Perbedaan intensitas nyeri dismenore yang dirasakan oleh setiap responden dapat disebabkan oleh perbedaan waktu dimulainya menstruasi dan perbedaan persepsi terhadap nyeri yang dialami (Padila, 2015). Pengalaman nyeri seseorang dipengaruhi oleh beberapa faktor yang kemudian dapat meningkatkan atau menurunkan persepsi nyeri tersebut, diantaranya: toleransi ataupun respon individu terhadap nyeri yakni pengalaman nyeri terdahulu, budaya, kecemasan, jenis kelamin, usia dan harapan terhadap upaya pemghilang nyeri (Hikmah, 2018).

Icemi \& Wahyu (2013) menjelaskan wanita yang mengalami dismenore atau nyeri menstruasi memiliki kadar prostaglandin yang 5-13 kali lebih tinggi dibandingkan dengan wanita yang tidak mengalami dismenore. Prostaglandin bisa menyebabkan meningkatnya aktivitas uterus dan serabut-serabut saraf terminal rangsang nyeri. Kombinasi antara meningkatnya kadar prostaglandin dan meningkatnya kepekaan miometrium mengakibatkan tekanan intra uterus sampai $400 \mathrm{mmHg}$ sehingga menyebabkan terjadinya kontraksi miometrium yang hebat.

\section{Skala Nyeri Dismenore Primer Sesudah Diberikan Terapi Masase Effleurage}

Berdasarkan hasil penelitian dapat dilihat bahwa setelah diberikan terapi masase effleurage dari 15 responden sebagian besar mengalami nyeri haid pada skala 1-3 (nyeri ringan).

Menurut peneliti hal ini terjadi karena faktor stres dari responden tersebut. Hal ini sesuai dengan teori menurut Anurogo \& Wulandari (2011) yang menyatakan bahwa faktor yang memegang peranan penting sebagai penyebab dismenore salah-satunya adalah faktor kejiwaan.Karena pada masa remaja labilnya emosi erat kaitannya dengan perubahan hormon dalam tubuh. Kusmiran (2012) menjelaskan pada wanita yang 
memiliki tingkat emosional tidak stabil, apalagi jika mereka tidak mendapat pengetahuan yang baik tentang proses haid, serta munculnya gejala dismenore.

Sejalan dengan penelitian Nurkhasanah \& Fitrisia (2014) dari hasil penelitian menunnjukkan bahwa nilai $\mathrm{p}=0,000$ sehingga terdapat perbedaan yang signifikan antara intensitas skala nyeri dismenore sebelum dan sesudah dilakukan masase effleurage.

Sejalan dengan penelitian Parulian et al., (2014) menunjukkan ada pengaruh teknik effleurage massage terhadap perubahan nyeri pada ibu post partum, dengan hasil p-value (0,000). Penelitian yang dilakukan Wulandari \& Hiba (2015) menunjukkan ada pengaruh massage effleurage terhadap pengurangan tingkat nyeri persalinan kala 1 fase aktif pada primigravida diruang bougenville RSUD Tugurejo Semarang, didapatkan pValue $=0,000$.

\section{Pengaruh Pemberian Terapi Masase Effleurage Abdomen terhadap Penurunan Skala Nyeri Dismenore Primer}

Hasil dalam penelitian ini menunjukkan bahwa mayoritas sampel dalam penelitian menyatakan bahwa setelah terapi masase effleurage merasakan adanya penurunan skala nyeri dismenore primer, artinya ada pengaruh pemberian terapi masase effleurage abdomen terhadap penurunan skala nyeri dismenore primer pada remaja putri di SMP Muhammadiyah Terpadu Kota Bengkulu.

Menurut peneliti bahwa adanya pengaruh pemberian terapi masase effleurage terhadap penurunan skala nyeri dismenore primer dikarenakan terapi masase effleurage yang diberikan membuat relaksasi otot abdomen sehingga sangat efektif untuk menurunkan rasa nyeri dismenore primer. Hal ini sejalan dengan teori gate control menurut Monsdragon bahwa serabut nyeri membawa stimulasi nyeri ke otak lebih kecil dan perjalanan sensainya lebih lambat dari pada serabut sentuhan yang luas (Nurkhasanah \& Fitrisia 2014). Ketika sentuhan dan nyeri dirangsang bersamaan, sensasi sentuhan berjalan keotak dan menutup pintu gerbang dalam otak, pembatasan jumlah nyeri dirasakan dalam otak.

Andarmoyo mengatakan bahwa rangsangan taktil dan perasaan positif berkembang ketika dilakukann bentuk sentuhan yang penuh perhatian dan empatik, dapat memperkuat efek effleurage massage untuk mengendalikan nyeri. Teknik ini dapat dilakukan tidak hanya untuk nyeri kontraksi uterus pada ibu post partum, tetapi dapat dilakukan untuk berbagai nyeri yang ditimbulkan dari stimulus lain (Andarmoyo, 2013).

Hasil penelitian ini sesuai dengan penelitian yang dilakukan oleh Parulian et al., (2014) yang melakukan penelitian tentang pengaruh teknik effleurage massage terhadap perubahan nyeri pada ibu post partum, hasil penelitian menjelaskan ada pengaruh teknik effleurage massage terhadap perubahan nyeri pada ibu post partum.

Penelitian yang dilakukan oleh Wulandari \& Hiba (2015) juga sesuai dengan penelitian ini, tentang pengaruh masase effleurage terhadap pengurangan tingkat nyeri persalinan kala 1 fase aktif pada primigravida di ruang Bougenville RSUD Tugurejo Semarang, hasil p-value $(0,000) \leq \alpha(0,05)$. Kesimpulan: Ada pengaruh massage effleurage terhadap tingkat nyeri persalinan kala I fase aktif pada ibu primigravida di Ruang Bougenville RSUD Tugurejo Semarang.

Hasil penelitian Wahyuningsih (2014) juga sesuai dengan penelitian ini, yang melakukan penelitian tentang efektivitas aromaterapi lavender (lavandula Angustifolia) dan masase effleurage terhadap tingkat nyeri persalinan kala 1 fase aktif pada primigravida di BPS UTAMI dan ruang PONEK RSUD Karanganyar. Hasil p-value 
$(0,000) \leq \alpha(0,05)$, yang berarti aromaterapi lavender (lavandula Angustifolia) dan masase effleurage efektif dalam menurunkan nyeri persalinan kala 1 fase aktif pada primigravida di BPS UTAMI dan ruang PONEK RSUD Karanganyar. Hasil penelitian Fauziyah (2013) pada Siswi SMAN 1 Gresik yang mengalami dismenore tahun 2013 menunjukkan bahwa teknik effleurage dapat menurunkan nyeri dismenore.

Hasil penelitian ini juga sesuai dengan penelitian yang dilakukan oleh Pangastuti (2011) di Pondok Pesantren Putri AL Munanwir Komplek Narussalam Krapyak Yogyakarta, hasil p-value $(0,000) \leq \alpha(0,05)$, yang berarti pemberian masage dapat menurunkan tingkat nyeri haid pada remaja.

\section{SIMPULAN}

Frekuensi skala nyeri dismenore primer sebelum diberikan terapi masase effleurage di SMP Muhammadiyah Terpadu Kota Bengkulu sebagian besar nyeri sedang (4-6).

Frekuensi skala nyeri dismenore primer sesudah diberikan terapi masase effleurage di SMP Muhammadiyah Terpadu Kota Bengkulu sebagian besar nyeri ringan (1-3).

Terdapat penurunan skala nyeri sebelum dan sesudah diberikan terapi masase effleurage abdomen terhadap nyeri dismenore primer pada remaja putri di SMP Muhammadiyah Terpadu Kota Bengkulu.

\section{SARAN}

\section{Bagi Petugas UKS SMP Muhammadiyah Terpadu Kota Bengkulu}

Untuk membantu remaja putri yang mengalami nyeri dismenore primer dalam menurunkan nyerinya. Diharapkan petugas UKS SMP Muhammadiyah Terpadu untuk memberikan informasi mengenai manfaat terapi masase effleurage terhadap nyeri sehingga penggunaan obat farmakologi bisa dikurangi.

\section{Bagi Perawat}

Terapi masase effleurage terbukti sangat efektif dalam menurunkan tingkat nyeri pasien dismenore primer, maka disarankan agar terapi masase effleurage dapat menjadi salah-satu intervensi mandiri keperawatan yang dapat dilakukan perawat untuk mengatasi respon nyeri pasien dismenore primer atau dalam manajemen nyeri, dan menjadi salah satu SOP dalam perawatan pasien nyeri dismenore primer.

\section{Bagi Peneliti Selanjutnya}

Hasil penelitian ini direkomendasikan untuk penelitian lebih lanjut tentang pengaruh masase effleurage pada pasien nyeri dismenore atau jenis nyeri yang lainnya dengan jumlah responden lebih banyak, kreteria yang lebih spesifik, waktu dan frekuensi yang lebih panjang, dan menggunakan desain metode penelitian yang lebih baik lagi, serta direkomendasikan juga untuk penelitian lebih lanjut tentang faktor yang lain yang mempengaruhi nyeri dismenore atau nyeri yang lain. 


\section{DAFTAR PUSTAKA}

Anurogo, D., \& Wulandari, A. (2011).Cara Mengatasi Nyeri Haid. Yogyakarta: CV. Andi

Apay, S., Arslan S., Akpinar R., \& Celeblioglu A. (2012). Effect of Aromatherapy Massage on Dismenore in Turkish Student. American Society for Pain Management Nursing, 13(4), 236-240

Calis, K. A. (2011). Dysmenorrhea. http://emedicine.medscape.com/article/253812overview

Fauziyah, I. Z. (2013). Efektivitas Teknik Effleurage dan Kompres Hangat terhadap Penurunan Tingkat Dismenore pada Siswi SMAN 1 Gresik. Skripsi. http://lppmunigresblog.files.wordpress.com/2013/06/jurnal-iin.pdf

Febriawati, H., Padila, P,. \& Anita, B. (2018). Pendidikan Seksual Remaja Melalui Poskesja. Jurnal Pengabdian Masyarakat Bumi Raflesia 1(1)

Hestiantoro, A. (2012). Masalah Gangguan Haid dan Infertilitas. Jakarta: FKUI

Hikmah, N., Amelia, C. R., \& Ariani, D. (2018). Pengaruh Pemberian Masase Effleurage Menggunakan Minyak Aromaterapi Mawar terhadap Penurunan Intensitas Nyeri Dismenore pada Remaja Putri di SMK Negeri 2 Malang Jurusan Keperawatan. Journal of Issues in Midwifery, 2(2), 34-45

Hurlock, E. B. (2010). Psikologi Perkembangan; Suatu Pendekatan Sepanjang Rentang Kehidupan (Alih Bahasa Istiwidayanti, et al), Edisi Kelima. Jakarta: Erlangga

Icemi, S., \& Wahyu, W. (2013). Buku Ajar Keperawatan Matenitas. Yogyakarta: Nuha Medika

Inayah, I. (2010). Hubungan Dismenore dengan Tingkat Kecemasan pada Siswi MTS Sudirman Kuwayuhan Pejagoan Kabumen. Skripsi. Sekolah Tinggi Ilmu Kesehatan Muhammadiyah Gombong

Kusmiran, E. (2012). Kesehatan Reproduksi Remaja dan Wanita. Jakarta: Salemba Medika

Nirwana, A. B. (2011). Psikologi Kesehatan Wanita (Remaja Menstruasi, Menikah, Hamil, Nifas, Menyusui). Yogyakarta: Nuha Medika

Nurkhasanah, N \& Fetrisia, W. (2014). Pengaruh Masase Effleurage terhadap Penurunan Intensitas Skala Nyeri Dismenore pada Siswi Kelas 1X MTsN Bukittinggi Tahun 2014. Jurnal Kesehatan STIKES Prima Nusantara Bukittinggi, $5(2)$

Padila, P. (2015). Asuhan Keperawatan Maternitas 1. Yogyakarta: Nuha Medika

Pangastuti, A. K. (2011). Pengaruh Masage terhadap Nyeri Haid pada Remaja di Pondok Pesantren Putri Al Munanwir Komplek Narussalam Krapyak Yogyakarta. Stikes Aisyiyah Yogyakarta

Parulian, T. S., Sitompul, J., \& Oktrifiana, A. N. (2014). Pengaruh Teknik Effleurage Massage terhadap Perubahan Nyeri pada Ibu Post Partum di Rumah Sakit Sariningsih Bandung . Jurnal Keperawatan, 4(2), 1-9

Prawirohardjo, S. (2011). Ilmu Kebidanan. Jakarta: Yayasam Bina Pustaka Sarwono

Prayitno, S. (2014). Buku Lengkap Kesehatan Organ Reproduksi Wanita. Yogyakarta: Saufa

Proverawati, P. (2012). Menarche Menstruasi Pertama Penuh Makna. Yogyakarta: Nuha Medika

Trisnowiyoto, B. (2012). Keterampilan Dasar Massage, Panduan Keterampilan Dasar Pijat Bagi Fisioterapis, Praktisi, dan Instruktur.Yogyakarta: Nuha Medika 
Wahyuningsih, M. (2014). Efektivitas Aromaterapi Lavender (Lavandula Angustifolia) dan Masase Effleurage terhadap Tingkat Nyeri Persalinan Kala 1 Fase Aktif pada Primigravida di BPS UTAMI dan Ruang PONEK RSUD Karanganyar. Stikes Kusuma Husada

Wulandari, W., \& Hiba, H. (2015). Pengaruh Masase Effleurage terhadap Pengurangan Tingkat Nyeri Persalinan Kala 1 Fase Aktif pada Primigravida di Ruang Bougenville RSUD Tugurejo Semarang. Jurnal Keperawatan Maternitas, 3(1) 